\title{
DETECTION AND CONFIRMATION OF FRESHWATER BLENNY Salaria fluviatilis (ACTINOPTERYGII: BLENNIIDAE) IN BOSNIA AND HERZEGOVINA
}

\author{
Pero Tutman ${ }^{1 *}$, Branko Glamuzina ${ }^{2}$ \\ ${ }^{1}$ Institute of Oceanography and Fisheries, Laboratory for Ichthyology and Coastal Fisheries, Šetalište Ivana \\ Meštrovića 63, 21000 Split, Croatia \\ 2 University of Dubrovnik, Department for Aquaculture, Ćira Carića 4, 20000 Dubrovnik, Croatia
}

*Corresponding Author: tutman@izor.hr

\section{ARTICLE INFO}

Received: 18 January 2021

Accepted: 30 January 2021

\section{ABSTRACT}

Distributional range of freshwater blenny Salaria fluviatilis extends to the tributaries along the Mediterranean and Black seas. It is considered endangered in several Mediterranean European countries. Although previously mentioned in the lists of freshwater fish species, its presence has never before been confirmed in Bosnia and Herzegovina. Consequently, this has led to doubts about its distribution there. A sample specimen of freshwater blenny was obtained from the lower Neretva River (Adriatic Sea watershed) in Bosnia and Herzegovina in May 2020, representing the first reliable record of this species. Considering that this record confirms older reports, however, it seems that earlier surveys have failed to locate the fish. Knowledge of the composition of fish species in river basins and updating their list are among the important requirements for managing the biodiversity of each country, as well as water and fish resources.

Tutman, P., Glamuzina, B. (2021): Detection and confirmation of freshwater blenny Salaria fluviatilis (ACTINOPTERYGII: BLENNIIDAE) in Bosnia and Herzegovina. Croatian Journal of Fisheries, 79, 75-82. DOI: 10.2478/cjf2021-0009. 


\section{INTRODUCTION}

Detailed knowledge of fish species diversity, in particular river basins, should be one of the key tasks of biodiversity as well as conservation management of each country. Periodic updating of the checklists according to new recorded changes in the composition and distribution of the species is a necessary basic tool for all competent national and regional fisheries management organisations. During such a process, it is also necessary to take into account the verification and accurate determination of especially those species that inhabit quite sensitive and diverse habitats such as river deltas and estuaries where masses of freshwater and seawater collide and mix, and form wide areas of brackish waters. The Neretva River and its delta is known as an area of rich biodiversity and extraordinary biological and ecological importance in the Mediterranean karst area (Mrakovčić et al., 2006; Smith and Darwall, 2006). Although extensive sampling has been carried out in the lower Neretva River watershed in Bosnia and Herzegovina to record existing ichthyofaunal compositions in the past (e.g. Kosorić et al., 1983, 1989; Mikavica, 1998), recent fish inventories in previously sampled areas have revealed new species which managed to escape scientific attention (Tutman et al., 2009, 2012, 2013, 2017a). However, following the aforementioned research, no targeted field sampling has been carried out in this area to update or confirm the overall species composition or status of fish fauna in the last 40 years. Therefore, it is considered that a complete description of existing species is still not close to being achieved (Tutman et al., 2017b, 2020a). Although this information is crucial for nature conservation and ecological research, there are serious gaps in our knowledge about the occurrence and distribution of fish species in this region (Tutman et al., 2020b).

Freshwater blenny Salaria fluviatilis (Asso 1801) is mainly a riverine species but can also be found in brackish river mouths, lakes and reservoirs (Changeux and Pont, 1995; Neat et al., 2003). Seasonally, it will tolerate brackish conditions but has fully adapted to survive and reproduce in freshwaters (Plaut, 1998). Its range extends through rivers and lakes that drain into the Mediterranean Sea (Albania, Croatia, France, Greece, Italy, Montenegro, Spain, Portugal, Turkey and Israel) as well as some Atlantic rivers in Morocco and Algeria (Zander, 1972; Changeux and Pont, 1995; Perdices et al., 2000). It prefers cobble and gravel substrate usually in streams with moderate to high current velocity and is often found in the deeper parts of streams (Freeman et al., 1990). Furthermore, it can also be found quite high and far from the river mouths, sometimes even above 500 m elevation (Alp and Kara, 2007). This species is of considerable biogeographical and high conservation interest because its populations are generally highly localized (Cote et al., 1999), and there is evidence of a decline in response to certain anthropogenic pressures (Vinyoles et al., 2002). This small fish can reach a length of $15 \mathrm{~cm}$, and sometimes is difficult to catch or to observe, so consequently it is often difficult to find out its status. Freshwater blenny is included in Annex III of the Bern Convention and is considered as Least Concern (LC) in the IUCN list (IUCN, 2020).

Salaria fluviatilis has already been reported in the lists of freshwaterfishes ofBosnia and Herzegovina(Vuković, 1963, 1977; Bogut et al., 2006; Sofradžija, 2009), but without detailed data on distribution, habitat ecology or biology. The lower Neretva River, which belongs to the Adriatic Sea watershed, has been mentioned as their potential distributional area, however, data on their distribution are based on very general information. Furthermore, no actual specimens with detailed description have ever been reported there (Kosorić, 1978; Kosorić et al., 1983; Mikavica, 1998). This has led to doubts about its presence there. The reliable data about its distribution were those for the Neretva River in Croatia, presented in Mrakovčić et al. (2006). Therefore, it is evident that essential information confirming the status and presence of freshwater blenny is missing, potentially making earlier reports unreliable. The uncertain status of $S$. fluviatilis in Bosnia and Herzegovina may cause an obstacle for planning and developing efficient conservation of this endangered and valuable species from a zoogeographic point of view. Although the information reported by previous authors above might be valid, suggesting that S. fluviatilis has already been distributed there, however, the data presented here with the pictures taken are the first solid proof of this species in Bosnia and Herzegovina freshwaters.

The aim of this study is to report the first reliable record of this species in Bosnia and Herzegovina and to confirm previously mentioned information.

\section{MATERIAL AND METHODS}

On 17 May 2020, a single nuptial male specimen of freshwater blenny (Fig. 1) was collected from the lower Neretva River in Bosnia and Herzegovina, near the village Doljani (lat. $43^{\circ} 03^{\prime} 11.43^{\prime \prime} \mathrm{N}$; long. $17^{\circ} 40^{\prime} 53.21^{\prime \prime} \mathrm{E}$; Fig. 2). The fish was accidentally caught in an eel trap at a water depth of $4 \mathrm{~m}$ in a site with partially bare sand and gravel, and partially overgrown by submerged vegetation. The information came from the fishermen who collected the specimen and sent us photo via WhatsApp. The distance from the sea was approximately $25 \mathrm{~km}$, while the altitudinal range of the area is $0.0 \mathrm{~m}$. The specimen was obtained at the invitation of fishermen, and the basic hydrographic parameters were measured on the same day. The water temperature was $17.2^{\circ} \mathrm{C}$, salinity $0.1 \mathrm{PSU}$. The sample specimen was kept in $70 \%$ ethanol prior to examination. 


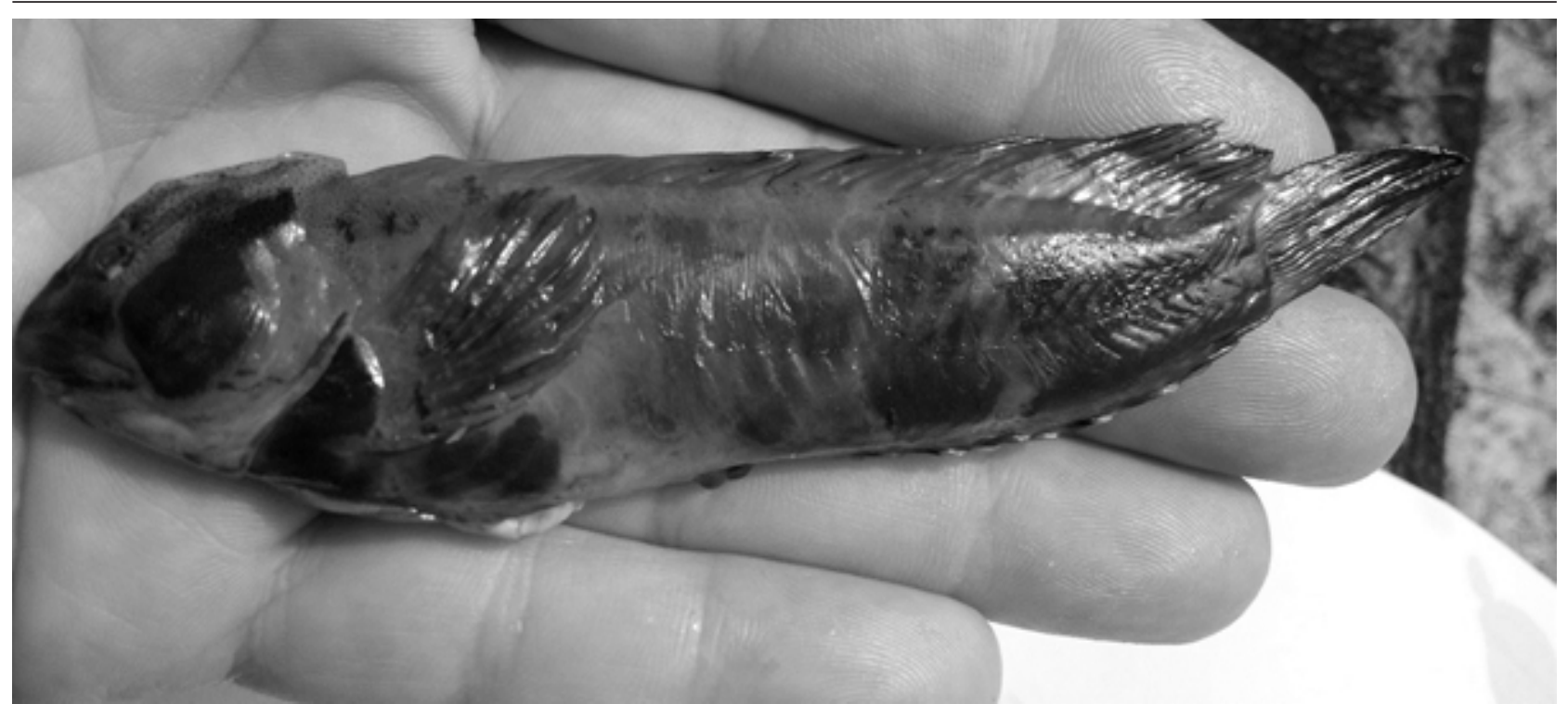

Fig 1. Freshwater blenny Salaria fluviatilis ( $T L=122 \mathrm{~mm}$ ) caught on 17 May 2020 in the lower Neretva River in Bosnia and Herzegovina (photo by Josip Vekić)

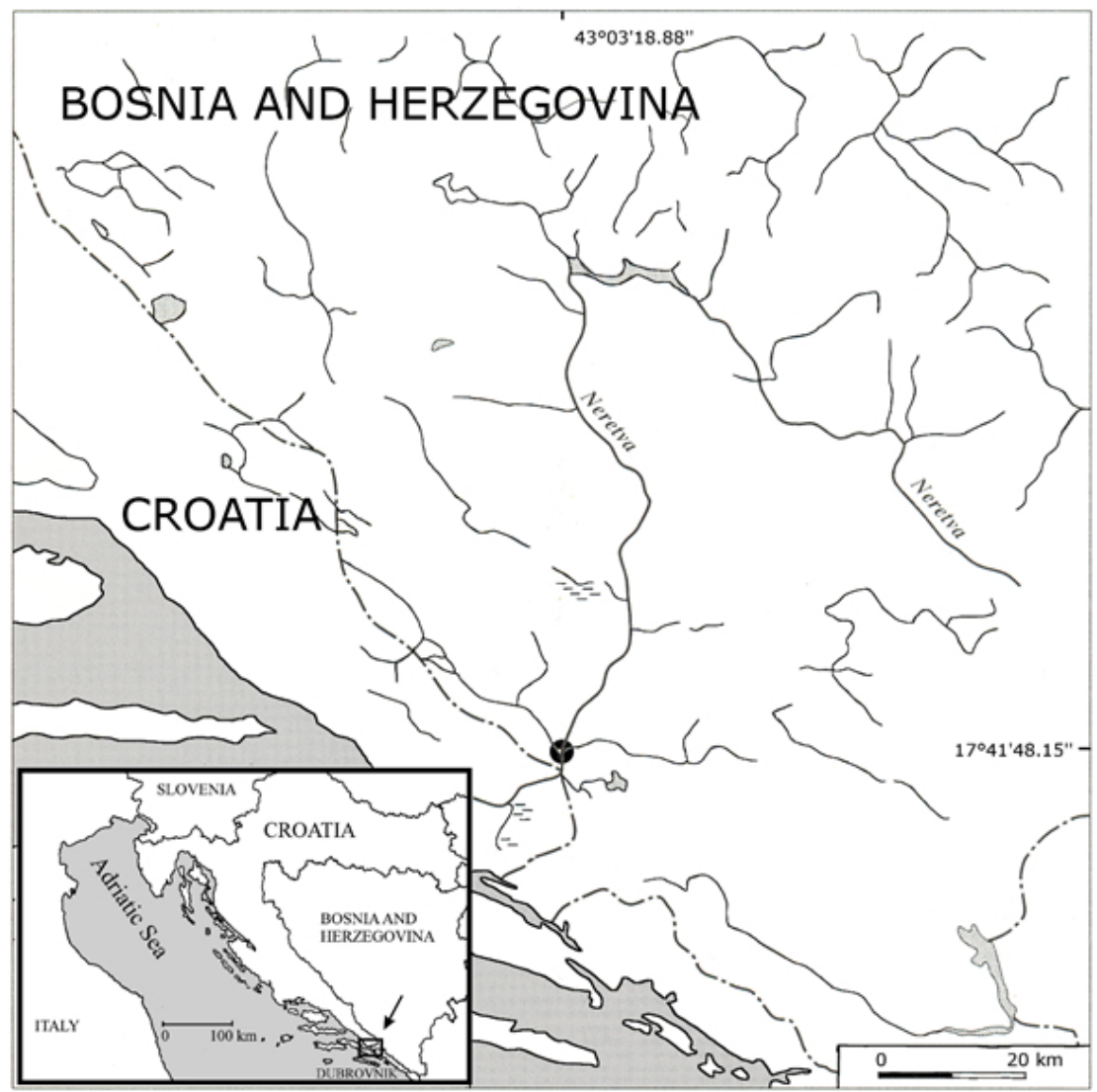

Fig 2. The Neretva River in Bosnia and Herzegovina with the collection location (black dot) of the described specimen of freshwater blenny Salaria fluviatilis 
Morphometric measurements were taken on the left side of the specimen using a digital calliper to the nearest $0.01 \mathrm{~mm}$ and were expressed as a percentage of standard length (SL). Total length ( $T L, \mathrm{~mm}$ ), standard length (SL, $\mathrm{mm}$ ) and total mass (BW, g) were also measured. A stereomicro-scope was used for the meristic characters. Morphometric methods followed Alp and Kara (2007), while meristic methods followed Kottelat and Freyhof (2007). Morphometric measurements and meristic characteristics of the specimen are presented in Table 1. The specimen was preserved in $5 \%$ buffered formalin and deposited in the Ichthyological Collection of the Institute of Oceanography and Fisheries in Split, Croatia, catalogue number IOR-SalFI 2020.

\section{RESULTS AND DISCUSSION}

This specimen has the typical combination of diagnostic features of $S$. fluviatilis presented in Kottelat and Freyhof (2007), including a broad diagonal band of tiny dots from the lower edge of eye downward backward, branched cirrus above eye, and dorsal ray formulae XIII+16 and anal ray formulae $\mathrm{II+16}$. In addition, this male has a blade-like light brown fleshy crest on its head uniformly pigmented with small dark dots. Furthermore, all meristics and morphometrics values and general morphology of the presently reported specimens are closely matching the features found by Alp and Kara (2007). However, since this is the only specimen caught, more detailed comparisons are not realistic.

Table 1. Morphometric (in $\mathrm{mm}$ ) and meristic data of freshwater blenny Salaria fluviatilis, caught in the lower Neretva River in Bosnia and Herzegovina. Measurements, except TL, SL and W are percentages of SL

\begin{tabular}{|c|c|c|c|}
\hline & & Parameter & Value \\
\hline & {$[\mathrm{mm}]$} & Total length (TL) & 122 \\
\hline & & Standard length (SL) & 101 \\
\hline & & Fork length & 21.36 \\
\hline & & Predorsal length & 27.97 \\
\hline & & Preanal lenght & 49.72 \\
\hline & & Preventral length & 21.32 \\
\hline & & Prepectoral lenght & 28.58 \\
\hline & & Dorsal fin lenght & 70.33 \\
\hline & & Dorsal fin depth & 6.87 \\
\hline & & Anal fin lenght & 51.27 \\
\hline & & Pectoral fin lenght & 27.11 \\
\hline \multirow[t]{12}{*}{ Morphometric measurements } & {$[\%$ of $T L]$} & Ventral fin lenght & 16.48 \\
\hline & & Caudal fin lenght & 20.68 \\
\hline & & Caudal peduncle depth & 10.17 \\
\hline & & Body depth (max) & 26.18 \\
\hline & & Body depth (min) & 10.03 \\
\hline & & Head lenght & 29.38 \\
\hline & & Head depth & 22.09 \\
\hline & & Snout length & 9.81 \\
\hline & & Ocular diameter (horiz.) & 3.41 \\
\hline & & Interorbital width & 4.51 \\
\hline & & Dorsal fin rays & $\mathrm{XIII+16}$ \\
\hline & & Anal fin rays & II+16 \\
\hline \multirow[t]{4}{*}{ Meristic counts } & & Pectoral fin rays & 13 \\
\hline & & Ventral fin rays & $2+2$ \\
\hline & & Caudal fin rays & 14 \\
\hline & & Weight (g) & 24.83 \\
\hline
\end{tabular}


For the biodiversity of each country, it is very important to update its species list and the composition of the species that live there with reliable scientific data. This has profound implications for implementing appropriate conservation strategies (Hume, 2017), if needed. Regardless of considerable biogeographical interest and high conservation value of freshwater blenny, the documented knowledge of the presence and detailed distribution in Bosnia and Herzegovina contained only general comments quoted from one paper to another (Vuković, 1963, 1977; Bogut et al., 2006; Sofradžija, 2009; Glamuzina et al., 2017) without any new information. Although freshwater blenny has previously been mentioned in the latest list of the freshwater fish fauna of Bosnia and Herzegovina (Sofradžija, 2009), this paper, for the first time, actually confirms previous information on their distribution in the lower course of the Neretva River from this country. Additional value is given by the data coupled with the exact locations and morphometric measurements and meristic characteristics of the specimen reported.

Although fish investigations in the lower Neretva River, especially in the Croatian part, have a long tradition (see Mrakovčić et al., 1995, 2006), there were no targeted reports registered in the scientific literature dedicated solely to $S$. fluviatilis. The findings described in this paper suggest that the species is distributed here which confirms previous authors (Vuković, 1963, 1977; Bogut et al., 2006; Sofradžija, 2009; Glamuzina et al., 2017) who assumed its occurrence although without a valid catch confirmation. However, this discrepancy might also be due to simple reasons. The obvious deficiency of scientific information in published literature is most probably associated with the lack of adequately targeted research, as well as sampling techniques; small size and lack of commercial value is the reason why they can easily be overlooked (Tutman et al., 2009, 2012, 2013). A great part of new findings in the lower Neretva River watershed arose from an increased sampling effort for several targeted scientific purposes (Tutman et al., 2009, 2012, 2013, 2017a). Therefore, the continuity of these samplings will undoubtedly reveal accurate data on new records of similar species populations. As such, similar efforts should be carefully extended to sites with no sampling efforts. In addition, the popularization of science through a published book (Glamuzina et al., 2017) on the Neretva River fishes contributed to local people's interest in the fish biodiversity and to the observation of the condition and occurrence of new or unknown fish species. The Neretva River watershed is one of biodiversity hotspots in the Mediterranean (Smith and Darwall, 2006). This stands in a stark contrast with a relatively low taxonomic knowledge of the fish species in the lower Neretva River. This shows that even with the increasing number of species findings over time, the knowledge of the actual number of fish species and respective geographical distributions in the area is far from complete.
In this paper, observation reported by individuals was used as a source of biodiversity data, which proved to be a significant source of quality information in the region (Dulčić and Tutman, 2015; Dulčić et al., 2017, 2018). Photographs are increasingly accepted as vouchers for primary biodiversity records if they are diagnostic and accompanied by high-quality metadata (Bacher, 2012). The availability of high-quality biodiversity information is vital to all aspects of biodiversity research, and in particular to efforts focused on biodiversity conservation and its sustainable use (Barve, 2014). In the last decades, a significant amount of information related to biodiversity changes in the Adriatic Sea has emerged as a result of activities other than conventional scientific samplings and surveys, e.g. through citizen reports, data obtained from social media, online surveys, etc. (Dulčić and Tutman, 2015; Dulčić et al., 2017, 2018). This way of obtaining information is especially important in cases when there is no comprehensive and targeted monitoring system in a particular area.

The distribution area of $S$. fluviatilis in the rivers of the Adriatic Sea watershed in neighbouring countries are very fragmented and localized; in Croatia it is discontinuously distributed along the coastline in the lower reaches of the rivers Zrmanja, Krka, Cetina and Neretva, Vransko and Visovac Lake (Mrakovčić et al., 2006), introduced in the Ričica, Otuča and Opsenica streams in the Lika plateau (Jelić et al., 2016). In Montenegro, it is found in the Morača River (Šanda et al., 2005) and Skadar Lake (Marić, 2018), as well as in Albania in the Vjosë River (Shumka et al., 2010). However still its distribution in Bosnia and Herzegovina is incompletely known, and its area of distribution as well as ecological conditions are not clear. Therefore, it is assumed that the presence of $S$. fluviatilis in Bosnia and Herzegovina is linked with the populations in the Neretva River in Croatia, although there are no detailed data about this population.

Salaria fluviatilis habitat preference was reported to be the lower course, a great distance from the source, with a lower mean gradient and lower altitude (Changeux and Pont, 1995). According to Hernandez et al. (2000), its habitats vary greatly in altitude, depth, stream velocity and bottom composition. In the present study, this species was found at sea-level altitudes. Salaria fluviatilis occurs in small populations in shallow waters $2-5 \mathrm{~m}$ deep, with low velocity, and bottoms of gravel and small stones (Bianco, 1995). However, as only one finding is included and elaborated in this paper, further research is certainly needed to obtain other important ecological data.

Although S. fluviatilis has no economical value, it is significant from the aspect of ichthyofaunal conservation and overall fish diversity as already stated by Cote et al. (1999). It is considered as Least Concern (LC) in the whole distribution area (IUCN 2020), but Vulnerable (VU) in Bosnia and Herzegovina (Škrijelj et al., 2013) and Croatia (Mrakovčić et al., 2006). The conservation status of freshwater fish is strongly linked to the size of 
their distribution range. Salaria fluviatilis is a species that lives over a very large general area (Mediterranean basin drainage), but prefers very specific microhabitats and can be considered elusive. Considering the lack of targeted research, the main information on the primary threats to freshwater blenny in Bosnia and Herzegovina can be derived from Škrijelj et al. (2013). Water pollution and habitat loss through modification of river substrates seems to be one of the major threats to freshwater blenny conservation, followed by the introduction of non-native species such as Lepomis gibbosus, Ameiurus gibbosus and Micropterus salmoides (Glamuzina et al., 2017).

The present record represents a new addition to the fish species list for Bosnia and Herzegovina, showing high biodiversity for the region. It is important to update species list distribution data because it is very important in a local and global perspective. Its deficiency can lead to wrong conclusions and decisions, mainly in the field of conservation and species management. Certainly, future reports and checklists should be more critical regarding similar reports and every new report data should be accompanied by at least a brief list of identification criteria, precise distributional area and a picture of the examined specimens. For better species inventory, finer scale distribution surveys are needed, followed by detailed morphological and ecological studies. This data will be particularly useful for all researchers interested in biodiversity in the lower Neretva River, Bosnia and Herzegovina and Croatia.

\section{ACKNOWLEDGEMENTS}

This work has been supported by Croatian Science Foundation (HRZZ) under the project IP-2016-06-5251. The authors are thankfull to Mr Josip Vekić who provided valuable information about the $S$. fluviatilis finding and support during the investigation.

\section{ZAPIS O RIJEČNOJ BABICI Salaria fluviatilis (ACTINOPTERYGII: BLENNIIDAE) U BOSNI I HERCEGOVINI}

\section{SAŽETAK}

Salaria fluviatilis je slatkovodna vrsta ribe čiji se raspon distribucije proteže na pritoke duž Sredozemnog i Crnog mora. Smatra se ugroženom u nekoliko europskih mediteranskih zemalja. lako je prethodno spomenuta na popisima slatkovodnih vrsta riba, njezino prisustvo zapravo nikada prije nije potvrđeno u Bosni i Hercegovini. Slijedom toga, došlo je do sumnje u njezinu distribuciju u tom području. Uzorak riječne babice dobiven je iz donjeg dijela rijeke Neretve (sliv Jadranskog mora) u Bosni i Hercegovini u svibnju 2020. godine, što predstavlja prvi pouzdan zapis o ovoj vrsti. S obzirom na to da ovaj zapis potvrđuje starija izvješća, iako ranija istraživanja nisu uspjela locirati ovu vrstu. Poznavanje sastava ribljih vrsta u riječnim slivovima i ažuriranje njihovog popisa jedan je od važnih zahtjeva za upravljanje biološkom raznolikošću svake zemlje, kao i vodenim i ribljim resursima.

Keywords: Biološka raznolikost, upravljanje, sliv Jadranskog mora, ažuriranje kontrolnih popisa

\section{REFERENCES}

Alp, A., Kara, C. (2007): Distribution pattern and morphological differences between the sexes of River Blenny, Salaria fluviatilis (Asso, 1801), in the Ceyhan River Basin, Turkey. Turkish Journal of Zoology, 31, 2, 113-120.

Bacher, S. (2012): Still Not Enough Taxonomists: Reply to Joppa et al. Trends in Ecology \& Evolution, 27, 2, 65-6.

Barve, V. (2014): Discovering and developing primary biodiversity data from social networking sites: A novel approach. Ecological Informatics, 24, 194-199.

Bianco, P.G. (1995): Mediterranean endemic freshwater fishes of Italy. Biological Conservation, 72, 2, 159-170.

Bogut, I., Novoselić, D., Pavličević, I. (2006): Biology of fishes. University of J.J. Strosmayer, University of Mostar, Faculty of Agriculture, Osijek. 620pp. [In Croatian.]

Changeux, T., Pont, D. (1995): Current status of the riverine fishes in the French Mediterranean basin. Biological Conservation, 72, 2, 137-158.

Cote, I.M., Vinyoles, D., Reynolds, J.D., Doadrioc, I., Perdices, A. (1999): Potential impacts of gravel extraction on Spanish populations of river blennies Salaria fuviatilis (Pisces, Blenniidae). Biological Conservation, 87, 359-367.

Dulčić, J., Dragičević, B., Ugarković, P., Tutman, P. (2017): The largemouth black bass (Micropterus salmoides) first record in the Neretva River delta, Adriatic drainage system of Croatia. Cybium, 41, 1, 77- 78.

Dulčić, J., Tutman, P. (2015): Additional record of common bream Abramis brama (Cyprinidae) in the Adriatic drainage system (Norin River, Croatia). Annales, Series historia naturalis, 25, 2, 145 - 148.

Dulčić, J., Tutman, P., Dragičević, B. (2018): On the occurrence of the Synodontis eupterus (Mochokidae) in the Adriatic drainage system of Croatia: a case of an introduced aquarium species and suggestions for alien species detection measures. Cybium, 42, 3, $297-298$.

Freeman, M.C., Vinolas, D., Grossman, G.D., De Sostoa, A. (1990): Microhabitat use by Blennius fluviatilis in the Rio Matarraña, Spain. Freshwater Biology, 24, 2, 335-346. Glamuzina, B., Pavličević, J., Tutman, P., Glamuzina, L., Bogut, I., Dulčić, J. (2013): Fishes of the Neretva River. CEAV, Mostar, Bosnia and Herzegovina and Modrozelena, Metković, Croatia. 263pp. [In Croatian.] 
Glamuzina, B., Tutman, P., Nikolić, V., Vidović, Z., Pavličević, J., Vilizzi, L., Copp, G.H., Simonović, P. (2017): Comparison of taxon-specific and taxon-generic risk screening tools to identify potentially invasive nonnative fishes in the River Neretva catchment (Bosnia and Herzegovina and Croatia). River Research and Applications, 33, 5, 670-679. DOI: 10.1002/rra.3124

Hernandez, R., Lacomba, R.T., Uvinas, Y.N., Oltra, R. (2000): Distribution of river blennies in the Jucar River basin (eastern Spain). Journal of Fish Biology, 57, 1, 250-254.

Hume, J.B. (2017): A review of the geographic distribution, status and conservation of Scotland's lampreys. Glasgow Naturalist, 26, 1-10.

IUCN (2020): The IUCN Red List of Threatened Species, version 2020-1. Downloaded on 20 July 2020. www. iucnredlist.org

Jelić, D., Špelić, I., Žutinić, P. (2016) Introduced species community over-dominates endemic ichthyofauna of high Lika plateau (Central Croatia) over a 100 year period. Acta Zoologica Academiae Scientiarum Hungaricae, 62.

Kosorić, Đ. (1978): The composition of the Hutovo Blato fish population. Godišnjak BIUS, 31, 69-81. [In SerboCroatian/ Croato-Serbian with English summary.]

Kosorić, Đ., Vuković, T., Guzina, N., Kapetanović, N., Mikavica, D. (1989): Ichthyofauna of the Neretva River and its changes after the building of hydroelectricity power stations. Pp. 133-138. In: Zbornik radova Savjetovanje o ribarstvu na hidroakumulacijama. Mostar, Yugoslavia. [In Serbo-Croatian/CroatoSerbian.]

Kosorić, Đ., Vuković, T., Kapetanović, N., Guzina, N., Mikavica, D. (1983): The composition of fish population of the Neretva River in Bosnia and Herzegovina. Godišnjak BIUS, 36, 117-128. [In Serbo-Croatian/ Croato-Serbian.]

Kottelat, M., Freyhof, J. (2007): Handbook of European freshwater fishes. Publications Kottelat, Cornol, Switzerland and Freyhof, Berlin, Germany. 646pp.

Marić, D. (2018): The Ichthyofauna of Lake Skadar/ Shkodra: Diversity, Economic Significance, Condition, and Conservation Status. pp. 363-381. In: Pešić, V., Karaman, G., Kostianoy, A. (eds), The Skadar/Shkodra Lake Environment. The Handbook of Environmental Chemistry, vol 80. Springer, Cham. 508pp.

Mikavica, D. (1998): The specific freshwater ichthyofauna of the hydrographic region of Bosnia and Herzegovina. Ichthyologia, 30, 1, 15-30.

Mrakovčić, M., Brigić, A., Buj, I., Ćaleta, M., Mustafić, P., Zanella, D. (2006): Red Book of freshwater fish of Croatia. Ministry of Culture, State Institute for Nature Protection, Republic of Croatia. Zagreb, Croatia. 253 pp. [In Croatian with English abstract.]

Mrakovčić, M., Mišetić, S., Povž, M. (1995): Status of freshwater fish in Croatian Adriatic river systems. Biological Conservation, 72, 2, 179-185.
Neat, F.C., Lengkeek, W., Westerbeek, E.P., Laarhoven, B., Videler, J.J. (2003): Behavioural and morphological differences between lake and river populations of Salaria fluviatilis. Journal of Fish Biology, 63, 2, 374387.

Perdices, A., Doadrio, I., Cote, I.M., Machordom, A., Economidis, P., Reynolds, J.D. (2000): Genetic divergence and origin of Mediterranean populations of the river Blenny Salaria fluviatilis (Teleostei: Blenniidae). Copeia, 2000, 3, 723-731.

Plaut, I. (1998): Comparison of salinity tolerance and osmoregulation in two closely related species of blennies from different habitats. Fish Physiology and Biochemistry, 19, 2, 181-188.

Šanda, R., Luskova, V., Vukić, J. (2005): Notes on the distribution and taxonomic status of Gobio gobio from the Morača River basin (Montenegro). Folia Zoologica, $54,1,73-80$.

Shumka, S., Shuka, L., Mali, S. (2010): Rivers Water Life and the Responses of Possible Hydropower's to be Constructed in the Water Courses of Vjosa, Semani and Drini in Albania. BALWOIS 2010 - Ohrid, Republic of Macedonia - 25, 29 May 2010.

Škrijelj, R., Lelo, S., Drešković, N., Sofradžija, A., TrožićBorovac, S., Korjenić, E., Lukić-Bilela, L., MitrašinovićBrulić, M., Kotrošan, D., Šljuka, S., Gajević, M., Karačić, J. (2013): Red list of Federation of Bosnia and Herzegovina. Book 3. EU Greenway, Sarajevo, Bosnia and Herzegovina. [In Bosnian.] http://www.ekoakcija. org/files/Crvena\%2Olista\%2OFaune\%2OFBiH.pdf

Smith, K.G., Darwall, W.R.T. (2006): The status and distribution of freshwater fish endemic to the Mediterranean basin. IUCN, Gland, Switzerland and Cambridge, UK. 34pp.

Sofradžija, A. (2009): Freshwater fishes of Bosnia and Herzegovina. Council of the Congress of Bosniak Intellectuals, Sarajevo, Bosnia and Herzegovina. 355pp. [In Bosnian.]

Tutman, P., Buj, I., Ćaleta, M., Hamzić, A., Korjenić, E., Adrović, A., Glamuzina, B. (2017b): Status and distribution of spined loaches (Cobitidae) and stone loaches (Nemacheilidae) in the Bosnia and Herzegovina. Folia Zoologica, 66, 4, 211-226.

Tutman, P., Buj, I., Ćaleta, M., Marčić, Z., Hamzić, A., Adrović, A. (2020a): Review of the lampreys (Petromyzontidae) in Bosnia and Herzegovina: a current status and geographic distribution. Journal of Vertebral Biology, 69, 1, 1-13. DOI:10.25225/jvb.19046

Tutman, P., Burić, M., Skaramuca, B. (2012): First substantiated record of the black-striped pipefish, Syngnathus abaster (Actinopterygii, Syngnathiformes, Syngnathidae): in the freshwaters of Bosnia and Herzegovina. Acta Ichthyologica et Piscatoria, 42, 3, $259-262$.

Tutman, P., Dulčić, J., Glamuzina, B. (2009): First record of Po brook lamprey, Lethenteron zanandreai 
(Cephalaspidomorphi, Petromyzontiformes, Petromizontidae): in the Hutovo Blato wetland, Bosnia and Herzegovina. Acta Ichthyologica et Piscatoria, 39, 1, 55-58.

Tutman, P., Freyhof, J., Dulčić, J., Glamuzina, B., Geiger, M. (2017a): Lampetra soljani, a new brook lamprey from the Southern Adriatic Sea basin (Petromyzontiformes: Petromyzontidae). Zootaxa, 4273, 4, 531-548.

Tutman, P., Šanda, R., Glamuzina, B., Dulčić, J. (2013): First confirmed record of Pomatoschistus canestrinii (Ninni, 1883) (Gobiidae) from Bosnia and Herzegovina. Journal of Applied Ichthyology, 29, 4, 937-939.

Tutman, P., Zanella, D., Horvatić, S., Hamzić, A., Adrović, A., Dulčić, J., Glamuzina, B. (2020b): Freshwater gobies (Gobiidae) of Bosnia and Herzegovina: a review of the current status and distribution. Journal of Vertebrate Biology, 69, 4, 20046.1-15.
Vinyoles, D., Cote, I., De Sostoa, A. (2002): Nest orientation patterns in Salaria fluviatilis. Journal of Fish Biology, 61, 2, 405-416.

Vuković, T. (1963): Fishes of Bosnia and Herzegovina (determination key).] The Institute for Publishing textbooks, Sarajevo, Yugoslavia. 127pp. [In SerboCroatian/ Croato-Serbian.]

Vuković, T. (1977): Fishes of Bosnia and Herzegovina. IGKRO Svjetlost, Sarajevo, Yugoslavia. 205pp. [In SerboCroatian/Croato-Serbian.]

Zander, C.D. (1972): Evolution of Blennioidei in the Mediterranean. Revue des travaux de l'Institut des peches maritimes, 37, 215-221. 